\title{
Analysis of the Documents Published in the Web of Science Database on Teachers' Gamification Method: A Content Analysis
}

\author{
https://doi.org/10.3991/ijet.v14i22.11741 \\ Zehra Ozcinar ${ }^{(凶)}$ \\ Atatürk Teacher Training Academy, Lefkosa, Cyprus, Turkey \\ zehra.ozcinareaoa.edu.tr \\ Venera G. Zakirova \\ Kazan (Volga region) Federal University, Kazan, Russia. \\ Rashad A. Kurbanov, Asiya M. Belyalova \\ Institute of Legislation and Comparative Law, Moscow, Russia
}

\begin{abstract}
Gamification is the use of game design elements in non-game contexts and it is gaining momentum in a wide range of areas including education. Despite increasing academic research exploring the use of gamification in education, little is known about teachers' main drivers and barriers to using gamification in their courses. Through the search conducted on Web of Science database with the keywords "teacher" and "gamification", the study is based on the analysis of the documents published. All articles published in Web of Science were examined. Their distribution by the years, subject areas, document types, organization, author, country/regions, sources, meeting titles, language and the research area theme have been examined. The varied findings reveal that the analysis of the studies published on Web of Science database is important in terms of content for the significance by teacher through gamification. Gamification is used by teacher for effective results. The findings of the review provide insights for further studies as well as for the design of gamified systems
\end{abstract}

Keywords-Gamification, Web of Science, content analysis, teachers

\section{Introduction}

Although technological advances and associated teaching methodologies represent new opportunities in education, but also present a challenge for teachers of higher education institutions [1]. Teachers should come up with questions about whether new teaching methodologies will be applied in their courses based on their beliefs about expected outcomes, performance, costs and benefits. For example, when applying a new instructional technology to a course, the associated costs may vary from personal costs (for example, up to the time devoted to preparing new instruction), materials to institutional costs (e.g. new equipment such as a digital whiteboard or computer) [2]. 
The rapid development of the new technology has changed the classroom teaching methods and tools in a positive way [3] [4] [5] [6]. Traditional schooling is perceived as ineffective and boring by many students. While teachers continuously seek novel instructional approaches, it is largely agreed that today's schools face major problems around student motivation and engagement [7] [8] [9] [33].

The use of game elements or games education is not new and can be traced back to the sixties when Piaget (1962) pointed out that games should not only help children to master their environments but also to create the worlds of their imagination [30].

Games also encourage students to play an active role in the learning process, thus supporting active learning, experiential learning and problem-based learning [10]. (Oblinger, 2004). Previous research has found that the use of games or play items in the classroom can also improve the classroom atmosphere [11]. In addition, the use of video games in the classroom can be attractive and motivating to future generations being raised in the age of video games [12] [13].

The Game Engine is hard to define; the term is somehow known in the game community, but few know what actually happened. This is due to the fact that the game engine comes in many ways and does it in real time [14]. The teaching of entrepreneurship is currently a fundamental pillar in the construction of social responsibility with strong impact on the future economic development of society. The use of serious games in the entrepreneurship field is a way of encouraging students' motivation to become entrepreneurs and develop their skills in the field [15]. Recently, many applications have begun to be developed with the advancement in the technology. In order to increase the effectiveness of these applications in education, mobile applications suitable for gamification method have become a contemporary issue [16] [32].

\subsection{Gamification}

It has attracted the attention of academics, practitioners and business professionals from various fields such as woolening, education, information studies, humancomputer interaction and health [17]. Nevertheless, while the term maintains its meaning in different meanings and contradictory uses, the concept derives from its academic value, underdeveloped theoretical foundations and the lack of a standardized guidelines for practice [18].

Deterding et al. (2011) [19]. say that the use of game design elements in non-game contexts is a fairly new and rapidly growing field. The concept of gamification is different from that of an educational or serious game. While the latter describes the design of full-fledged games for non-entertainment purposes, "gamified" applications merely employ elements of games. According to Deterding, Dixon, Khaled and Nacke (2011), the term "gamification" is quite new [20].

Gamification is the use of game design elements in non-game contexts and is gaining momentum in a wide range, including education [2]. Meaningful gamification is the use of fun and entertaining layers to help the user find personal connections that motivate interaction with a particular context for long-term change. While rewardbased gamification can be useful for short-term goals and situations where participants do not have personal ties or intrinsic motivation to involve in a context, rewards 
can reduce real motivation and desire to take part in the long-term real-world context [21].

The literature review reveals that a few many studies conducted on gamification. The purpose of this study is to analyze the research conducted by teacher through the method of gamification. Under the scope of this general aim, the answers to the following sub-objectives are sought for:

- How are the documents distributed over the years?

- How is the distribution according to subject areas?

- How is the distribution according to document type?

- How is the distribution according to organizations?

- How is the distribution according to author?

- How is the distribution according to country/regions?

- How is the distribution according to sources?

- How is the distribution according to meeting titles?

- How is the distribution according to languages?

- How is the distribution according to research areas?

\subsection{The purpose of the study}

The purpose of this study is to systematically analyze the articles accessed through search on Web of Science database with keywords selected by examining according to designated themes through discussing with other related basic concepts. Through the research the views regarding the use of gamification by teacher will be evaluated to contribute to further studies in the related subject areas.

\subsection{Limitations}

This research is limited to the selected and reviewed documents in the Web of Science database, is limited to the documents published between the years 2013 and 2018, accessed through Near East University Web of Science database, and The content analysis of the documents is limited to the 10 themes specified above.

\section{Methodology}

\subsection{Method}

The study was conducted by using document analysis and related content analysis among qualitative research methodology. The basic process in content analysis is to compile similar data within the framework of the mentioned concepts and themes and interpret them in a way that the readers can understand [22]. Content analysis is a scientific framework that allows a systematic analysis of written, oral and other sources [23]. Cohen, Manion, and Morrison (2007) describe content analysis as presenting the messages contained in the present documents in a concise manner [24]. 


\subsection{Data collection and analysis}

In order to learn the work of teachers in the field of gamification, Web of Science documents were examined. Primarily a search was conducted on Web of Science database using the keywords "teacher and gamification" between the years 2013 and 2018 and the search yielded 337 documents which are presented in Figure 1. The documents retrieved through the Web of Science database are analyzed, integrated by correlation with each other and the data was analyzed through content analysis.

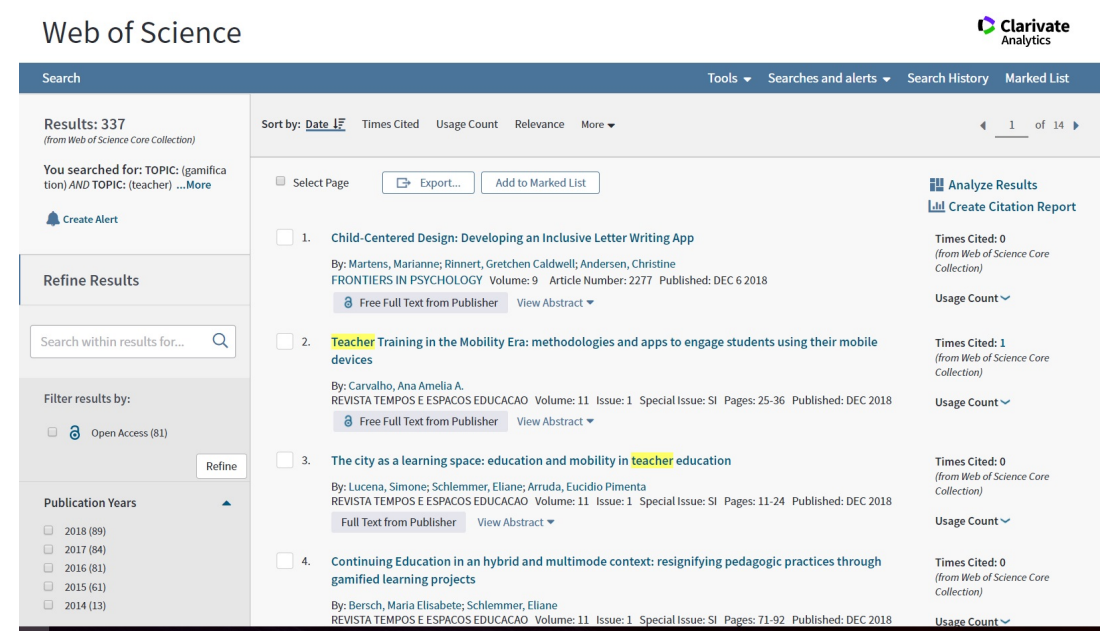

Fig. 1. The documents accessed on Web of Science database through keywords "teacher and gamification"

\section{Results}

\subsection{The distribution of the documents by years}

At this stage of the research, the distribution of the documents between the years 2013 and 2018 are examined. In this context, 337 studies are accessed through Web of Science database, their distribution is presented in Table 1.

Table 1. Distribution of the Documents by Years

\begin{tabular}{|c|c|c|}
\hline Years & f & \% of 337 \\
\hline 2018 & 89 & $26.41 \%$ \\
\hline 2017 & 84 & $24.93 \%$ \\
\hline 2016 & 81 & $24.04 \%$ \\
\hline 2015 & 61 & $18.10 \%$ \\
\hline 2014 & 13 & $3.86 \%$ \\
\hline 2013 & 9 & $2.67 \%$ \\
\hline
\end{tabular}


Table 1 shows the distribution of 337 studies obtained from the analysis by years. When the distribution by years is considered, it is seen that the highest value is in $2018(\mathrm{f}=89)$ and second highest value is in $2017(\mathrm{f}=84)$. Similarly, Table 1 shows that the lowest values are seen in $2013(\mathrm{f}=9)$ and $2014(\mathrm{n}=13)$.

The main point that draws attention according to the data in Table 1 is that research on teacher and gamification has been on the rise in recent years. It can be said that this number will increase gradually in the coming years.

\subsection{Distribution of the documents by subject areas}

Table 2. Distribution of the Documents by Subject Areas

\begin{tabular}{|l|c|}
\hline \multicolumn{1}{|c|}{ Subject Areas } & f \\
\hline Education Educational Research & 212 \\
\hline Computer Science Interdisciplinary Applications & 38 \\
\hline Computer Science Theory Methods & 34 \\
\hline Education Scientific Disciplines & 34 \\
\hline Computer Science Information Systems & 27 \\
\hline Engineering Electrical Electronic & 23 \\
\hline Psychology Multidisciplinary & 12 \\
\hline Computer Science Artificial Intelligence & 10 \\
\hline Telecommunications & 10 \\
\hline Social Sciences Interdisciplinary & 9 \\
\hline
\end{tabular}

Table 2 shows the ranking of 337 articles obtained from the analyzes according to research areas. In the distribution of teachers' studies related to gamification according to research areas, it is seen that "education, educational research" has the highest ( $\mathrm{f}=$ 212) and "Computer Science Interdisciplinary Applications" has the second highest value $(\mathrm{f}=38)$.

It is known that this ranking is an expected result, and that gamification is one of the different learning methods with respect to the alternative learning methods, and the applications in the fields of education and educational research are handled and given directions scientifically. In addition, the field of gamification is being developed as an interdisciplinary field, on the basis of computer science and educational research.

\subsection{Distribution of the documents by document types}

Table 3. Distribution of the Documents by Document Types

\begin{tabular}{|l|c|c|}
\hline \multicolumn{1}{|c|}{ Document Type } & f & \% of 337 \\
\hline Proceedings paper & 219 & $64.99 \%$ \\
\hline Article & 113 & $33.53 \%$ \\
\hline Book chapter & 6 & $1.78 \%$ \\
\hline Review & 5 & $1.48 \%$ \\
\hline Editorial material & 2 & $0.59 \%$ \\
\hline
\end{tabular}


When Table 3 is examined, the distribution of the document types of researches related to teachers and gamification is seen. Considering this information, "Proceedings paper" ( $f=219)$ has the highest value among the data, followed by "Article" $(f=113)$ and "Book Chapter" ( $f=6)$ at third place. It stands out that when it is compared, "Proceedings paper" document type is quite more than other document types. The lack of research on gamification allows researchers to present, discuss and expand their work as proceedings at conferences and congresses.

When an area is getting developed, first of all, the results of the research are presented to the participants of the congresses. It is then replicated as an article publication with an increasing acceleration.

\subsection{Distribution of the documents by the organizations}

Table 4. Distribution of the Documents by the Organizations

\begin{tabular}{|l|c|}
\hline \multicolumn{1}{|c|}{ Organizations-Enhanced } & f \\
\hline Univ Europea Valencia & 11 \\
\hline University of Valencia & 8 \\
\hline Universidade Federal De Pernambuco & 5 \\
\hline Aalborg University & 4 \\
\hline Complutense University of Madrid & 4 \\
\hline Consiglio Nazionale Delle Ricerche Cnr & 4 \\
\hline Instituto Politecnico De Braganca & 4 \\
\hline Istituto Per Le Tecnologie Didattiche Itd Cnr & 4 \\
\hline Nord University & 4 \\
\hline Univ Europea Canarias & 4 \\
\hline
\end{tabular}

When Table 4 shows the distribution of teachers and authors of the researches about gamification towards their institutions. Considering this information, the university with the highest value becomes European Valencia University ( $\mathrm{f}=11$ ) and the university with the second highest value becomes University of Valencia $(f=8)$. It is seen that other institutions are ranked from four (4) to one (1). The most attentiongrabbing point is that the most article publishing institutions are from same city, Valencia, Spain with researchers from different universities. This means that the researchers collaborate or work together when they are in close contact with each other, and thus, naturally inspired by one another, allowing them to increase production. 


\subsection{Distribution of the documents by the author}

Table 5. Distribution of the Documents by the Author

\begin{tabular}{|l|c|c|c|}
\hline \multicolumn{1}{|c|}{ Authors } & f & \% of 337 & Bar Chart \\
\hline Marti-Parreno J & 12 & $3.56 \%$ & $3.561 \%$ \\
\hline Sanchez-Mena A & 8 & $2.37 \%$ & $2.374 \%$ \\
\hline Aldas-Manzano J & 4 & $1.19 \%$ & $1.187 \%$ \\
\hline Dagnino Fm & 4 & $1.19 \%$ & $1.187 \%$ \\
\hline Hew KF & 4 & $1.19 \%$ & $1.187 \%$ \\
\hline Lopes Rp & 4 & $1.19 \%$ & $1.187 \%$ \\
\hline Nordby A & 4 & $1.19 \%$ & $1.187 \%$ \\
\hline Schulz R & 4 & $1.19 \%$ & $1.187 \%$ \\
\hline Bittencourt II & 3 & $0.89 \%$ & $0.890 \%$ \\
\hline Botha A & 3 & $0.89 \%$ & $0.890 \%$ \\
\hline
\end{tabular}

Table 5 shows the distribution of the findings obtained when the studies related to teachers and gamification are ranked according to the author's rank. In Table 5, it is seen that Marti-Parreno J published the most articles $(f=12)$, followed by SanchezMena with 8 articles. According to these findings, it is seen that more researchers are needed in the field of gamification and teacher, and in addition to that, the research is more spread to general rather than a certain researcher' dominance in the field.

\subsection{Distribution of the documents by the countries of authors}

In Table 6, it is seen that Spain takes first $(f=79)$ and Brazil second place $(f=31)$ in the distribution of teachers and authors of the studies on gamification by country. According to these results, it is seen that Spain attaches more importance to gamification in education and training applications. Another remarkable point is that China produced only 9 studies. In recent years, since China has been a country that pushed the top positions in science and technology researches, obtaining low numbers in research on teachers and gamification is highly thought-provoking.

Table 6. Distribution of the Documents by the Countries of Authors Countries/Regions

\begin{tabular}{|l|c|c|}
\hline \multicolumn{1}{|c|}{ Countries/Regions } & f & \% of 337 \\
\hline Spain & 79 & $23.44 \%$ \\
\hline Brazil & 31 & $9.20 \%$ \\
\hline Portugal & 18 & $5.34 \%$ \\
\hline England & 17 & $5.05 \%$ \\
\hline Italy & 17 & $5.05 \%$ \\
\hline USA & 16 & $4.75 \%$ \\
\hline Norway & 10 & $2.97 \%$ \\
\hline Germany & 9 & $2.67 \%$ \\
\hline Greece & 9 & $2.67 \%$ \\
\hline Peoples R China & 9 & $2.67 \%$ \\
\hline
\end{tabular}




\subsection{Distribution of the documents by the sources}

Table 7. Distribution of the Documents by the Sources

\begin{tabular}{|l|c|c|}
\hline \multicolumn{1}{|c|}{ Source Titles } & f & $\%$ of 337 \\
\hline Proceedings of The European Conference on Games Based Learning & 27 & $8.01 \%$ \\
\hline ICERI Proceedings & 26 & $7.72 \%$ \\
\hline INTED Proceedings & 25 & $7.42 \%$ \\
\hline EDULEARN Proceedings & 22 & $6.53 \%$ \\
\hline 10th International Conference of Education Research and Innovation ICERI-2017 & 12 & $3.56 \%$ \\
\hline Lecture Notes in Computer Science & 12 & $3.56 \%$ \\
\hline 12th International Technology Education and Development Conference UNTED & 11 & $3.26 \%$ \\
\hline $\begin{array}{l}\text { EDULEARN-15 7th International Conference on Education and New Learning Tech- } \\
\text { nologies }\end{array}$ & 11 & $3.26 \%$ \\
\hline ICERI-2016 9th International Conference of Education Research and Innovation & 10 & $2.97 \%$ \\
\hline $\begin{array}{l}\text { EDULEARN-16 8th International Conference on Education and New Learning Tech- } \\
\text { nologies }\end{array}$ & 9 & $2.67 \%$ \\
\hline
\end{tabular}

Table 7 shows the first three ranks of the studies on teacher and gamification according to the sources published; "Proceedings of the European Conference on Games Based Learning $(f=27)$ comes at first place, followed by "ICERI Proceedings" ( $f=$ $26)$ and "INTED Proceedings" ( $f=25)$, which are almost equal in value.

Considering the information in Table 7 , it is seen that the most publications are published in "conference proceedings", and there is no specific journal about Gamification and teachers. It can be argued that this result stems from the fact that Gamification is a relatively new field.

\subsection{Distribution of the documents by the source's languages}

Table 8. Distribution of the Documents by the Articles Languages

\begin{tabular}{|l|c|c|}
\hline \multicolumn{1}{|c|}{ Languages } & f & \% of 337 \\
\hline English & 299 & $88.72 \%$ \\
\hline Spanish & 23 & $6.83 \%$ \\
\hline Portuguese & 12 & $3.56 \%$ \\
\hline Bulgarian & 1 & $0.30 \%$ \\
\hline Croatian & 1 & $0.30 \%$ \\
\hline Russian & 1 & $0.30 \%$ \\
\hline
\end{tabular}

Table 8 shows the distribution of publication languages of teachers and gamification studies by years. When Table 8 is examined, it is seen that the highest number is in English ( $\mathrm{f}=299,88.72 \%)$ and Spanish comes second ( $\mathrm{f}=23,6.83 \%)$. According to this result, it is revealed that English, as in other fields, is dominant in the researches about teacher and gamification as a science language. However, it can be said that Spanish is on a remarkable rise. 


\section{Discussion and Conclusion}

In the research designed as content analysis that is initiated with the search conducted on Web of Science database with the keywords "teacher and gamification", 10 themes are specified and a total of 337 documents are accessed and the documents are analyzed with regards to those specified themes. According to this, when the by years distribution of the documents published between the years of 2013 and 2018 is analyzed, the studies conducted by teacher through gamification increased in time while the highest number of studies, 89 , are conducted in 2018. Popular interest in gamification has been reflected in the academic context and the number of papers published in gamification is growing. Hamari, Koivisto and Sarsa (2014) gave an overview of the increasing number of articles on the subject. Apparently, it is especially noteworthy that the term "gamification art" increases in the titles, even faster than general search results [25]. This suggests gamification has become a more popular academic research topic. The result of this study is consistent with the results of other studies [25].

When the researches on the gamification method of teachers are examined, it is seen that the most work is done in the field of "Education Educational Research". It is seen that the least number of studies were conducted in the field of Social Sciences Interdisciplinary.

When the researches on the gamification method of teachers are examined, it is seen that most of the studies on gamification method of teachers are published as conference papers. When the studies are examined, 2 documents are published as the editorial material. According to these findings, it is concluded that the articles are written as conference papers and the publication is less. Hamari, Koivisto and Sarsa, (2014) [25]; Bicen, Kocakoyun (2017) [16]; found that most of the research done with gamification are published as conference papers. This result is supported by the literature.

When the studies conducted by teachers about gamification are examined, it is seen that the organization that makes the most work is University Europea Valencia (11). Aalborg University, Complutense University of Madrid, Consiglio Nazionale Delle Ricerche Cnr, Instituto Politecnico De Braganca, Istituto Per Le Tecnologie Didattiche Itd Cnr, Nord University, University Europea Canarias conducted 4 studies.

When the studies are examined, it is seen that author MARTI-PARRENO J (12) is the author with the highest level of gamification and teachers' studies. BOTHA A. and BITTENCOURT have 3 studies in the web of science index.

When the countries of authors of the studies on gamification between the years 2013 and 2018 are analyzed, it is revealed that the majority of the studies are conducted in "Spain" (79). This is followed by 4 study from "China", "Greece" and "Germany". The number of this kind of researches is needed to increase in Turkey. "China", "Greece" and "Germany" refer to the studies that could not enter the list of Turkey. This must be achieved in Turkey by concluding the increase of working with gamification [9] [26].

When the sources of authors of the studies on gamification between the years 2013 and 2018 are analyzed, it is seen that "Proceedings of the European Conference on Games Based Learning" has 27 studies, and the least number of studies is from EDU- 
LEARN 8TH international conference on education and new learning technologies (9).

When the sources of authors of the studies on gamification between the years 2013 and 2018 are analyzed, it is seen that most of them are conducted in "10th Annual International Conference of Education Research and Innovation ICERI" (12) and "12th International Technology Education and Development Conference INTED. (11)", and being the least number is "11th International Conference on Technology Education and Development Inted." research (5).

When the sources of authors of the studies on gamification between the years 2013 and 2018 are analyzed and examined, it is seen that they are published in English (299). The least number of studies were written in Russian, Bulgarian and Crotian (1). Uzunboylu and Kocakoyun (2017), Turan Çimşir and Uzunboylu (2019), Kayımbaşıoğlu, Oktekin and Hacı (2016) concluded that most of the literature are written in English. This result stems from the fact that English is a universal language [27] [28] [29].

When the studies performed by the teachers using gamification are examined, it is seen that the highest level of education is in the field of "Education Educational Research" (228). It is seen that it is done in the field of "Business Economics (4) at least. Dicheva, Dichev, Agre and Angelova (2015), Yıldırım (2017), Kirillov, Vinichenko, Melnichuk, Melnichuk and Vinogradova (2016) concluded that most of the literature on education is in the field of "Education" [31] [34].

\section{Acknowledgement}

The work is performed according to the Russian Government Program of Competitive Growth of Kazan Federal University.

\section{References}

[1] Brown, W. L., \& Gilchrist, W. J. (2016). Assessing productivity to address safety concerns for information technology and promoting global standardization within aviation practices. Global Journal of Information Technology: Emerging Technologies, 5(2), 56-61. https:// doi.org/10.18844/gjit.v5i2.195

[2] Sánchez-Mena, A., and Martí-Parreño, J. (2017). Drivers and Barriers to Adopting Gamification: Teachers' Perspectives. Electronic Journal of e-Learning, 15(5), 434-443.

[3] Keser, H., Uzunboylu, H., and Özdaml, F. (2011). The trends in technology supported collaborative learning studies in 21st century. World Journal on Educational Technology, 3(2). Retrieved September 12, 2015, from: http://www.world-education-center.org/index. $\mathrm{php} / \mathrm{wjet} /$ article/view/256

[4] Dewitt, D., and Siraj, S. (2011). Learner's perceptions of technology for design of a collaborative mLearning module. World Journal on Educational Technology, 2(3). Retrieved September 1, 2015, from: http://www.world-education-center.org/index.php/wjet/article/ view/172

[5] Uzunboylu, H., and Karagözlü, D. (2015). Flipped classroom: a review of recent literature. World Journal on Educational Technology, 7(2). Retrieved September 18, 2016, from: 
http://www.world-educationcenter.org/index.php/wjet/article/view/3871. https://doi.org/ 10.18844/wjet.v7i2.46

[6] Özcan, D., and Genç, Z. (2016). Pedagogical Formation Education via Distance Education. Eurasia Journal of Mathematics, Science and Technology Education, 12(2), 347-360

[7] Lee, J., and Hammer, J. (2011). Gamification in Education: What, How, Why Bother? Academic Exchange Quarterly, 15(2), 146

[8] Dicheva, D., Dichev, C., Agre, G., and Angelova, G. (2015). Gamification in education: A systematic mapping study. Educational Technology and Society, 18(3), 75-88.

[9] Bicen, H., and Bal, E. (2016). Determination of student opinions in augmented reality. World Journal on Educational Technology: Current Issues, 8(3), 205-209. https://doi.org/ 10.18844/wjet.v8i3.642

[10] Oblinger, D. G. (2004). The Next Generation of Educational Engagement. Journal of Interactive Media in Education, 8(1), 1-18.

[11] Yang, Y. C. (2012). Building virtual cities, inspiring intelligent citizens: Digital games for developing students' problem solving and learning motivation. Computers and Education, 59(2), 365-377 https://doi.org/10.1016/j.compedu.2012.01.012

[12] Glover, I. (2013). Play as you learn: Gamification as a technique for motivating learners. In J. Herrington, A. Couros and V. Irvine. (Eds.), Proceedings of World Conference on Educational Multimedia, Hypermedia and Telecommunications 2013, (pp. 1999-2008). Chesapeake, VA: AACE.

[13] Martí-Parreño, J., Seguí-Mas, D., and Seguí-Mas, E. (2016). Teachers' attitude towards and actual use of gamification. Procedia-Social and Behavioral Sciences, 228, 682-688. https://doi.org/10.1016/j.sbspro.2016.07.104

[14] Salama, R., and ElSayed, M. (2018). Basic elements and characteristics of game engine. Global Journal of Computer Sciences: Theory and Research, 8(3), 126-131. https://doi. org/10.18844/gjcs.v8i3.4023

[15] Almeida, F. (2017). Experience with entrepreneurship learning using serious games. Cypriot Journal of Educational Sciences, 12(2), 69-80. https://doi.org/10.18844/cjes.v12i2. 1939

[16] Bicen, H., and Kocakoyun, S. (2017). Determination of university students' most preferred mobile application for gamification. World Journal on Educational Technology: Current Issues, 9(1), 18-23. https://doi.org/10.18844/wjet.v9i1.641

[17] Kohnova, L., \& Papula, J. (2018). Key differences in perceiving innovation between businesses that see the strategic importance of innovation and those that only claim to be innovative. Global Journal of Business, Economics and Management: Current Issues, 7(2), 216-224. https://doi.org/10.18844/gjbem.v7i2.2951

[18] Seaborn, K., and Fels, D. I. (2015). Gamification in theory and action: A survey. International Journal of human-computer studies, 74, 14-31. https://doi.org/10.1016/j.ijhcs.2014. $\underline{09.006}$

[19] Deterding, S., Dixon, D., Khaled, R., and Nacke, L. (2011). From Game Design Elements to Gamefulness: Defining "Gamification". In A. Lugmayr et al. (Ed.), MindTrek 2011 (pp. 9-15). Tampere, Findland: ACM. MindTrek Conference: Envisioning Future Media Environments, pp. 9-15. https://doi.org/10.1145/2181037.2181040

[20] Deterding, S., Dixon, D., Khaled, R., and Nacke, L., 2011. From game design elements to gamefulness: defining gamification. In Proceedings of the 15th International Academic https://doi.org/10.1145/2181037.2181040

[21] Nicholson, S. (2015). A recipe for meaningful gamification. In Gamification in education and business (pp. 1-20). Springer, Cham. https://doi.org/10.1007/978-3-319-10208-5_1 
[22] Yıldırım, A., and Şimşek, H. (2006). Sosyal bilimlerde nitel araştırma yöntemleri (Qualitative research methods in social sciences) Ankara: Seckin Yayınları.

[23] Tavşancıl, E., and Aslan, A. E. (2001). Sözel, yazılı ve diğer materyaller için içerik analizi ve uygulama örnekleri (Content analysis and application examples for verbal, written and other materials). Epsilon.

[24] Cohen, L. M., and Manion, L. (2001). 1. and Morrison, K. (2007). Research methods in education, 6 .

[25] Hamari, J., Koivisto, J., and Sarsa, H. (2014, January). Does Gamification Work?-A Literature Review of Empirical Studies on Gamification. In HICSS (Vol. 14, No. 2014, pp. 30253034). https://doi.org/10.1109/hicss.2014.377

[26] Pektaş, M., and Kepçeoğlu, İ. (2019). What Do Prospective Teachers Think about Educational Gamification? Science Education International, 30(1), 65-74.

[27] Uzunboylu, H., and Kocakoyun, S. (2017). A content analysis of master and doctorate thesis in the area of gamification. International Journal of Innovative Research in Education, 3(3), 143-154.

[28] Turan Cimșir, B., and Uzunboylu, H. (2019). Awareness training for sustainable development: Development, implementation and evaluation of a mobile application. Sustainability, 11(3), 611. https://doi.org/10.3390/su11030611

[29] Kayımbaşıoglu, D., Oktekin, B., and Hac1, H. (2016). Integration of gamification technology in education. Procedia Computer Science, 102, 668-676. https://doi.org/10.1016/j. procs.2016.09.460

[30] Piaget, J. (1962). Play, dreams and Imitation in Childhood. New York: W.W. Norton and Co.

[31] Kirillov, A. V., Vinichenko, M. V., Melnichuk, A. V., Melnichuk, Y. A., and Vinogradova, M. V. (2016). Improvement in the learning environment through gamification of the educational process. International Electronic Journal of Mathematics Education, 11(7), 20712085.

[32] Hasan, Ã., Kanbul, S. and Özdaml, F. (2018). Effects of the gamification supported flipped classroom model on the attitudes and opinions regarding game-coding education. International Journal of Emerging Technologies in Learning (iJET), 13(1), 109-123. https://doi.org/10.3991/ijet.v13i01.7634

[33] Rikawarastuti, R., Ngatemi, N., and Yusro, M. (2018). Development of web-based dental health ladder snake game for public elementary school students in Indonesia. World Journal on Educational Technology: Current Issues, 10(1), 20-28. https://doi.org/10.18844/ wjet.v10i1.3327

[34] Yildırım, I. (2017). The effects of gamification-based teaching practices on student achievement and students' attitudes toward lessons. The Internet and Higher Education, 33, 86-92. https://doi.org/10.1016/j.iheduc. 2017.02.002

\section{$7 \quad$ Authors}

Zehra Özçınar graduated from Küçük Kaymaklı Teacher Training College, completing a degree in BSc Primary School Teacher in 1991. She graduated from Ankara University; completed a degree in MA Curriculum and Instruction in 1995 and completed PhD in area of Educational Technology in 2003. She is Associate Professor of Educational Technology area in 2012 at Ataturk Teacher Training Academy in North Cyprus. Email: zehra.ozcinar@aoa.edu.tr 
Venera G. Zakirova is a Doctor of Education, Professor, Head of the Department of Preschool and Primary Education of the Institute of Psychology and Education at Kazan (Volga region) Federal University (18 Kremlyovskaya Street, 420000, Kazan, Russia). Her research interests are connected with the problems of childhood, their health and successfulness. She has more than 70 published papers in international journals. E-mail: zakirovav-2011@,mail.ru

Rashad A. Kurbanov is a Doctor in Law, Professor of the Department of Legal Basis of the Economic Activity at the Institute of Legislation and Comparative Law under the Government of the Russian Federation (34 Cheryomushkinskaya Street, 117218, Moscow, Russia). He is well known in Russia with his scientific works dedicated to the different problems of government, legislation and comparative law. He is also interested on the problems concerning the methodology of scientific works. E-

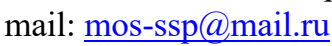

Asiya M. Belyalova is a Head of International Cooperation Department at the Institute of Legislation and Comparative Law under the Government of the Russian Federation (34 Cheryomushkinskaya Street, 117218, Moscow, Russia). She has more than 80 published scientific works in Russia and other countries dedicated to different problems of law methodology. E-mail: asyulya@mail.ru

Article submitted 2019-09-23. Resubmitted 2019-10-19. Final acceptance 2019-10-21. Final version published as submitted by the authors. 